\title{
Inorganic Polymers from a Plasma Convertor Slag: Effect of Activating Solution on Microstructure and Properties
}

\author{
Lubica Kriskova $^{1} \cdot$ Lieven Machiels $^{1} \cdot$ Yiannis Pontikes $^{1}$
}

Published online: 18 July 2015

(C) The Minerals, Metals \& Materials Society (TMS) 2015

\begin{abstract}
Plasma processing of materials is a technology now also employed in the management of municipal solid wastes, often mixed with industrial residues. The specifics depend per case, but typically the process delivers energy, in the form of a gas or heat, a metal-rich fraction as well as a slag. The slag, containing mainly $\mathrm{Si}-, \mathrm{Fe}-, \mathrm{Ca}-$ and $\mathrm{Al}-$ oxides, is almost completely amorphous after rapid cooling and thus could possibly be used as precursor in the synthesis of inorganic polymers (IP). The latter is explored in the present work. Slag resembling the composition of refuse-derived fuel ash was mixed with various $\mathrm{Na}$-silicate activating solutions, and the effect of $\mathrm{SiO}_{2} / \mathrm{Na}_{2} \mathrm{O}$ as well as $\mathrm{H}_{2} \mathrm{O} / \mathrm{Na}_{2} \mathrm{O}$ molar ratio on the synthesis and mechanical properties of the prepared IP was investigated. It was found that for $\mathrm{SiO}_{2} /$ $\mathrm{Na}_{2} \mathrm{O}$ molar ratios of 1.2 and $\mathrm{H}_{2} \mathrm{O} / \mathrm{Na}_{2} \mathrm{O}$ molar ratio of 30.8 , the mechanical strength of casted IP reached almost $90 \mathrm{MPa}$ after 90 days. Further decrease in the $\mathrm{SiO}_{2} / \mathrm{Na}_{2} \mathrm{O}$ ratio, accompanied by decrease in the $\mathrm{H}_{2} \mathrm{O} / \mathrm{Na}_{2} \mathrm{O}$ ratio, increased the early strength and the released reaction heat, but had no effect on the late strength. In addition to that, crack formation was pronounced. The increase of the concentration of activating solution, by means of reducing the water content level, i.e. $\mathrm{H}_{2} \mathrm{O} / \mathrm{Na}_{2} \mathrm{O}$, resulted in an increase of the released reaction heat as well as an increase of the mechanical strength, up to $112 \mathrm{MPa}$ at 90 days. The above results are relevant to a range of metallurgical slags and other vitreous by-products and contribute towards more high added-value applications.
\end{abstract}

The contributing editor for this article was Yiannis Pontikes.

Lubica Kriskova

lubica.kriskova@mtm.kuleuven.be

1 Department of Materials Engineering, KU Leuven, Kasteelpark Arenberg 44, 3001 Leuven, Belgium
Keywords Inorganic polymer · Geopolymer - Slag · Recycling · Building material

\section{Introduction}

In a plasma gasification process, refuse-derived fuel from municipal solid wastes (MSW) as well as various other industrial residues, are subjected to a one or two stage process, delivering energy, in the form of a gas or heat, a metal-rich fraction as well as a slag [1]. The plasma convertor slag from these installations consists mainly of Si-, $\mathrm{Fe}-, \mathrm{Ca}-$ and $\mathrm{Al}$-oxides, while other elements, such as $\mathrm{Na}$, $\mathrm{Mg}, \mathrm{Zn}, \mathrm{Ti}$ and $\mathrm{Cu}$ are present in rather small quantities [2]. The resulting slag, if subjected to high cooling rates during solidification by means of e.g. granulation, is mainly amorphous. If lower cooling rates are applied, a range of crystalline phases, such as quartz $\left(\mathrm{SiO}_{2}\right)$, magnetite $\left(\mathrm{Fe}_{3} \mathrm{O}_{4}\right)$, wüstite $(\mathrm{FeO})$, hercynite $\left(\mathrm{FeAl}_{2} \mathrm{O}_{4}\right)$, anorthite $\left(\mathrm{CaAl}_{2} \mathrm{Si}_{2} \mathrm{O}_{8}\right)$, augite $\left((\mathrm{Ca}, \mathrm{Na})(\mathrm{Mg}, \mathrm{Fe}, \mathrm{Al}, \mathrm{Ti})(\mathrm{Si}, \mathrm{Al})_{2} \mathrm{O}_{6}\right)$, periclase $(\mathrm{MgO})$ or lime $(\mathrm{CaO})$, may be present $[3,4]$.

Considering both chemical as well as mineralogical composition, plasma convertor slag from MSW, together with $\mathrm{Fe}-\mathrm{Ni}$ slag, $\mathrm{Pb}, \mathrm{Cu}$ and $\mathrm{Zn}$ slag, falls into a large group of industrial by-products containing a Fe-rich glass fraction. Apart from the chemistry resemblance, it also appears that high temperature (metallurgical-like) processing is now employed in the treatment of MSW. For instance, in Japan, JFE (a company resulting from the merger of NNK Steel and Kawasaki Steel) as well as Nippon Steel, have developed Waste to Energy (WtE) plants employing direct melting technology $[5,6]$ whereas more recently, Hitachi Metals [7] introduced plasma-assisted $\mathrm{WtE}$ units. Thus, the slag producing process as well as the slag itself are falling to a substantial extent within 
the area of metallurgy, even if undoubtedly the focus is not placed on the metal itself.

Substantial volumes of these slags are generated annually, with their applications typically being of low-added value, such as, abrasive tools or aggregates in concrete or asphalt [8]. The use of these materials as precursors in the synthesis of inorganic polymers (IP) seems to be a promising way for higher added value applications as well as a contribution to sustainability, considering that the IP constitutes a smaller $\mathrm{CO}_{2}$ footprint binder compared to traditional portland cement (OPC) $[9,10]$. The term "inorganic polymer" herein refers to materials consisting of a polymer or polymer network with a skeletal structure that does not include carbon atoms [11]. The chemical composition of these materials can vary widely, but when aluminosilicate-rich precursors are used, the term geopolymer, named so in 1976 by Davidovits [12], seems to prevail in the literature. The focus of this work is placed on iron-aluminosilicates, originating from non-ferrous slags or vitrified residues from MSW.

In the area of non-ferrous slags, Onisei et al. [13] studied the reactivity of a fayalite slag, concluding that this precursor could indeed be converted to an IP, with the activating solution being a crucial parameter in terms of process kinetics. In another study, Onisei et al. [14] used various mixtures of fly ash and $\mathrm{Pb}$ slag for the synthesis of IP. They claimed that IP prepared from $70 \mathrm{wt} \% \mathrm{~Pb}$ slag and $30 \mathrm{wt} \%$ fly ash reached a compressive strength of $47 \mathrm{MPa}$, while $\mathrm{Si}$, $\mathrm{Fe}, \mathrm{Na}$ and $\mathrm{Pb}$ were detected in the binding phase. Leaching was evaluated for $\mathrm{pH}$ in a range of 5-12.5, and it was demonstrated that $\mathrm{Pb}$ leaching decreased, while $\mathrm{Zn}$ and $\mathrm{As}$ leaching increased compared to the leaching of raw materials. Kalinkin et al. [8] synthesised IP using a mechanically activated Cu-Ni slag. They reached $81 \mathrm{MPa}$ of compressive strength after 28 days, whereas when the $\mathrm{Cu}-\mathrm{Ni}$ slag was mechanically activated in $\mathrm{CO}_{2}$ atmosphere, the 28th day strength increased to $94 \mathrm{MPa}$. Komnitsas et al. [15, 16] investigated the feasibility of IP synthesis from low-Ca electric arc ferronickel slags. They showed that it is possible to synthesise IP from this slag, and depending on the activating solution and curing, they reached $50 \mathrm{MPa}$ of compressive strength after 7 days. Furthermore, they stated that the curing period had the highest effect on the mechanical strength, next to other factors, such as initial water content, alkali concentration and activator, procuring period as well as heating temperature and heating time (during curing). Maragkos et al. [17] approached the IP synthesis from $\mathrm{Fe}-\mathrm{Ni}$ slag as a multi-factorial problem investigating the solid to liquid ratio $(\mathrm{S} / \mathrm{L})$, the initial sodium hydroxide and the silica concentrations in the aqueous phase. It was found that the $\mathrm{S} / \mathrm{L}$ ratio was a crucial parameter for the compressive strength, the latter increasing as a linear function of the S/L ratio for the range of the studied values. In another work,
Sakkas et al. [18] synthesised IP from Fe-Ni slag activated with $7 \mathrm{M} \mathrm{NaOH}$ solution. The resultant material shows a low thermal conductivity of $0.135 \mathrm{~W} / \mathrm{mK}$ and could be characterised as fire-resistant material.

In the area of slags which originate from vitrified MSW, Pontikes et al. [4] studied the effect of cooling rates during solidification on the precursor's structure, how the latter influences the dissolution of $\mathrm{Al}$ and $\mathrm{Si}$, as well as, the formation and mechanical properties of synthesised IP. It was demonstrated that cooling is an important parameter, affecting the microstructure and slag dissolution in alkalis, and ultimately the properties of resulting IP. Yamaguchi et al. [19] used various urban waste-incinerated slags for the synthesis of IPs. Both Fe-rich and Fe-poor slags were used, and as an activating solution, a mixture of water glass and a $10 \mathrm{M} \mathrm{NaOH}$ solution (with the volume ratio 3:1) was employed. They observed that samples cured at $80{ }^{\circ} \mathrm{C}$ and $100 \%$ humidity reached a flexural strength of 3-16 MPa. Interestingly, the main factor influencing the strength was not the amount of $\mathrm{Fe}$, as had been expected, but the degree of swelling and foaming which was caused by the generation of hydrogen from the residual $\mathrm{Al}$ present in the slags. In the work of Machiels et al. [3], the microstructure of IP from Fe-silicate glasses was investigated, while modifying the activating solution to solid (L/S) mass ratio. They showed, that lowering the L/S ratio resulted in a denser IP with less cracks and a higher compressive strength. The above listed papers demonstrate that $\mathrm{Fe}$-rich slags have a clear potential for being used as precursors for IP synthesis.

The present work falls in the domain of Fe-rich slags and aspires to shed light on the processing towards IP. This is done by investigating the effect of activating solution on the formation and properties of IP while keeping the addition of alkalis to as low as possible levels. This work is a part of a bigger project, where the authors and colleagues explore under what conditions the vitrification of municipal solid waste can lead to a combined production of energy and materials, thus, establishing a "Waste-to-Resources" process.

\section{Materials and Methods}

The slag studied was prepared by mixing analytical grade chemicals in order to reach the desired composition representing the chemistry of a glass produced in a plasma conversion process [20], Table 1 . The materials were mixed for at least $12 \mathrm{~h}$ using $1-\mathrm{cm}$ diameter $\mathrm{ZrO}_{2}$ milling balls (Turbula T2C). The mixture was placed in a Pt crucible and heated in a bottom loading furnace (AGNI ELT $160-02)$ at $1723 \mathrm{~K}$, with an isothermal soaking step of $1.5 \mathrm{~h}$, followed by water quenching. The aim of the preparation process was to resemble the slag melting and subsequent vitrification in a WtE plasma installation. 
Table 1 Chemical composition of plasma convertor slag

\begin{tabular}{llllllllll}
\hline $\mathrm{SiO}_{2}$ & $\mathrm{CaO}$ & $\mathrm{Fe}_{2} \mathrm{O}_{3}$ & $\mathrm{Al}_{2} \mathrm{O}_{3}$ & $\mathrm{Na}_{2} \mathrm{O}$ & $\mathrm{MgO}$ & $\mathrm{ZnO}$ & $\mathrm{TiO}_{2}$ & $\mathrm{CuO}$ & $\mathrm{Others}$ \\
\hline 33.6 & 21.7 & 19.9 & 11.9 & 4.0 & 3.4 & 1.9 & 1.7 & 1.1 & 0.9 \\
\hline
\end{tabular}

The produced material was first milled below $250 \mu \mathrm{m}$ in a centrifugal mill (Retsch, ZM100) and then further milled in a ball mill (Retsch, PM4) for 20 min at $200 \mathrm{rpm}$ using 5 -mm diameter stainless steel milling balls. The particle size distribution was determined using laser scattering (MasterSizer Micro Plus, Malvern). Each powder was analysed three times, and the average values were recorded.

The mineralogy was determined by X-ray diffraction analysis (XRD, PW 1830 Philips) using $\mathrm{CuK} \alpha$ radiation of $45 \mathrm{kV}$ and $30 \mathrm{~mA}$. The X-ray patterns were collected with a step size of $0.02^{\circ}$ and step time of $2 \mathrm{~s}$. Quantitative XRD results were obtained adopting the Rietveld method [21, 22]. $\mathrm{ZnO}$ was used as an internal standard to determine the amorphous content.

Two sets of inorganic polymer paste samples were prepared by mixing the milled slag (s) with Na-silicate activating solution (1). In the first set, the effect of $\mathrm{SiO}_{2} / \mathrm{Na}_{2} \mathrm{O}$ molar ratio on the IP properties was investigated while the s:1 mass ratio was kept constant at 1:0.58, Table 2. In the second set, the $\mathrm{SiO}_{2} / \mathrm{Na}_{2} \mathrm{O}$ molar ratio was kept constant and equal to S3 sample (this sample showed good results from the first experimental campaign), and the s:1 was increased by means of reducing the water content, Table 3 . In both cases, the Si/Al molar ratio was kept at 2.8. The synthesised inorganic polymer samples were placed in plastic containers and stored closed at room temperature.

Reaction kinetics were determined on paste samples by means of in-situ isothermal calorimetry at $293 \mathrm{~K}$ (TAM Air device, TA Instruments). To investigate the reaction in the long term, pastes were stored in closed plastic cups for 7 and 90 days. After the designated time period, the samples were crushed in an agate mortar and dried in a vacuum-freeze dryer (Alpha 1-2 LD, Martin Christ) at 0.035 mbar for $2.5 \mathrm{~h}$. Thermogravimetric analysis (TGA) was carried out on paste samples using the simultaneous TGA/DSC (STA 409 PC Luxx ${ }^{\circledR}$, Netzsch). The samples were heated at $10 \mathrm{~K} / \mathrm{min}$ in a continuous $\mathrm{N}_{2}$ flow up to $1273 \mathrm{~K}$. Fourier transformed infrared spectroscopy (FTIR) spectra on pastes were collected by means of a platinum ATR QuickSnap ${ }^{\text {TM }}$ sampling module (Alpha spectrometer, Bruker), which allows direct measurement of powder samples. Microstructural investigation was performed using scanning electron microscopy (SEM, XL30 Philips). Pastes were dried for a week at $293 \mathrm{~K}$ and relative humidity of $60 \%$. The dry samples were subsequently embedded in resin, polished and gold coated. Wavelength dispersive spectroscopy (WDS) was used for chemical composition mapping on the IP samples using an accelerating voltage of $15 \mathrm{kV}$ (JXA-8530F, JEOL).

Mortar samples were prepared by mixing the milled slag with CEN standard sand keeping the binder to sand mass ratio at 1:3. The activating solution was added to the dry mixture, and a homogeneous mortar sample was prepared using a bench mixer. The samples were placed into plastic containers with dimensions of $25 \times 25 \times 20 \mathrm{~mm}^{3}$ and stored in a closed way at room temperature for the designated period. Mercury intrusion porosimetry (MIP, Micromeritics AutoPore IV) was used for the determination of pore size distribution in mortar samples cured for 90 days. The compressive strength was measured on cubic mortar samples cured for 7, 28, and 90 days, at a crosshead speed of $2 \mathrm{~mm} / \mathrm{min}$. From each group, three samples were measured, and the average values were recorded.

\section{Results}

\section{Material Characterisation}

The quenched slag was glassy and of dark brown to black colour. The originally produced granules disintegrated into smaller angular fragments, most probably due to the presence of high internal stresses induced during rapid

Table 2 Mixtures' compositions for 1st set of samples, given ratios are molar

\begin{tabular}{|c|c|c|c|c|c|c|c|}
\hline \multirow[t]{2}{*}{ Sample } & \multicolumn{2}{|l|}{ Solution (1) } & \multicolumn{5}{|c|}{ Sample $(s+1)$} \\
\hline & $\mathrm{SiO}_{2} / \mathrm{Na}_{2} \mathrm{O}$ & $\mathrm{H}_{2} \mathrm{O} / \mathrm{Na}_{2} \mathrm{O}$ & $\mathrm{Na} / \mathrm{Al}$ & $\mathrm{H}_{2} \mathrm{O} /\left(\mathrm{Al}_{2} \mathrm{O}_{3}+\mathrm{SiO}_{2}\right)$ & $\mathrm{Na}_{2} \mathrm{O} /\left(\mathrm{Al}_{2} \mathrm{O}_{3}+\mathrm{Fe}_{2} \mathrm{O}_{3}\right)$ & $\mathrm{s}: 1$ & Water content (wt $\%$ ) \\
\hline S1 & 2.0 & 54.5 & 1.0 & 3.5 & 0.48 & 1.7 & 31.70 \\
\hline $\mathrm{S} 2$ & 1.5 & 39.0 & 1.1 & 3.4 & 0.55 & 1.7 & 30.97 \\
\hline S3 & 1.2 & 30.8 & 1.3 & 3.4 & 0.62 & 1.7 & 30.31 \\
\hline S4 & 1.0 & 25.6 & 1.4 & 3.3 & 0.68 & 1.7 & 29.71 \\
\hline S5 & 0.9 & 22.0 & 1.5 & 3.2 & 0.74 & 1.7 & 29.14 \\
\hline
\end{tabular}


Table 3 Mixtures' compositions for 2nd set of samples, given ratios are molar

\begin{tabular}{|c|c|c|c|c|c|c|c|}
\hline \multirow[t]{2}{*}{ Sample } & \multicolumn{2}{|l|}{ Solution (1) } & \multicolumn{5}{|c|}{ Sample $(s+1)$} \\
\hline & $\mathrm{SiO}_{2} / \mathrm{Na}_{2} \mathrm{O}$ & $\mathrm{H}_{2} \mathrm{O} / \mathrm{Na}_{2} \mathrm{O}$ & $\mathrm{Na} / \mathrm{Al}$ & $\mathrm{H}_{2} \mathrm{O} /\left(\mathrm{Al}_{2} \mathrm{O}_{3}+\mathrm{SiO}_{2}\right)$ & $\mathrm{Na}_{2} \mathrm{O} /\left(\mathrm{Al}_{2} \mathrm{O}_{3}+\mathrm{Fe}_{2} \mathrm{O}_{3}\right)$ & $\mathrm{s}: 1$ & Water content (wt\%) \\
\hline S3 & 1.2 & 30.8 & 1.3 & 3.4 & 0.62 & 1.7 & 30.31 \\
\hline S6 & 1.2 & 26.8 & 1.3 & 2.9 & 0.62 & 1.9 & 27.46 \\
\hline S7 & 1.2 & 22.2 & 1.3 & 2.4 & 0.62 & 2.2 & 23.90 \\
\hline
\end{tabular}

cooling. The XRD results and the Rietveld analysis revealed that the water quenched slag was almost completely amorphous, $>98 \mathrm{wt} \%$; quartz $\left(\mathrm{SiO}_{2}\right)$ and magnetite $\left(\mathrm{Fe}_{3} \mathrm{O}_{4}\right)$ were identified as the only crystalline phases present. The mean particle size $\left(\mathrm{d}_{50}\right)$ of the milled slag was $\sim 17 \mu \mathrm{m}$, and the values of $\mathrm{d}_{10}$ and $\mathrm{d}_{90}$ were equal to 1 and $95 \mu \mathrm{m}$, respectively.

\section{Reactivity}

The isothermal calorimetry curves, Fig. 1, show the released heat of the IP pastes during the first $100 \mathrm{~h}$ of reaction. This heat is released from the dissolution, reorganisation, gelation and polymerisation stages of IP synthesis [23], in addition to the very early heat of wetting [24]. In terms of kinetics, heat release was recorded almost immediately after mixing, in all cases, except for the $\mathrm{S} 1$ sample, and a significant influence of the $\mathrm{SiO}_{2} / \mathrm{Na}_{2} \mathrm{O}$ ratio of the activating solution on the total values was evident. In fact, at early times, the rate of heat release and thus reaction rate seem comparable for all compositions, except for $\mathrm{S} 1$, but at later times, the reaction rate decreases faster for higher ratios of $\mathrm{SiO}_{2} / \mathrm{Na}_{2} \mathrm{O}$. One can see that the lower the $\mathrm{SiO}_{2} / \mathrm{Na}_{2} \mathrm{O}$ ratio of the activating solution, the higher the heat release was after $100 \mathrm{~h}$. The largest differences occurred between the S1 and S2 samples and between the S4 and S5 samples. In the first case, the lower molar ratio caused an increase in the total heat released from $15 \mathrm{~J} / \mathrm{g}$ (S1) to $30 \mathrm{~J} / \mathrm{g}$ (S2). In the second case, the total heat released was raised from $42 \mathrm{~J} / \mathrm{g}$ (S4) to $52 \mathrm{~J} / \mathrm{g}$ (S5). Sample $\mathrm{S} 3$ was in between, at $35 \mathrm{~J} / \mathrm{g}$ after $100 \mathrm{~h}$. This trend was expected, presuming that the small fluctuation in $\mathrm{H}_{2} \mathrm{O}$ content (Table 2) is insignificant, as it was also found in other cases that a transition to a more silicate-rich activating solution results in lower total heat release [25]. This is attributed to the different potential of the activating solutions employed in the study, for hydrolysis of the -Al$\mathrm{O}-\mathrm{Si}-$ and $-\mathrm{Si}-\mathrm{O}-\mathrm{Si}-$ linkages in the slag. It is thus expected that moving from S1 to S5 solutions, more slag dissolution and extended formation of the new binder occur. The previous statement corresponds with the SEM results (presented later, Fig. 5), where it is clearly visible that the dissolution of the particles was indeed more pronounced in samples activated with more alkaline solutions.
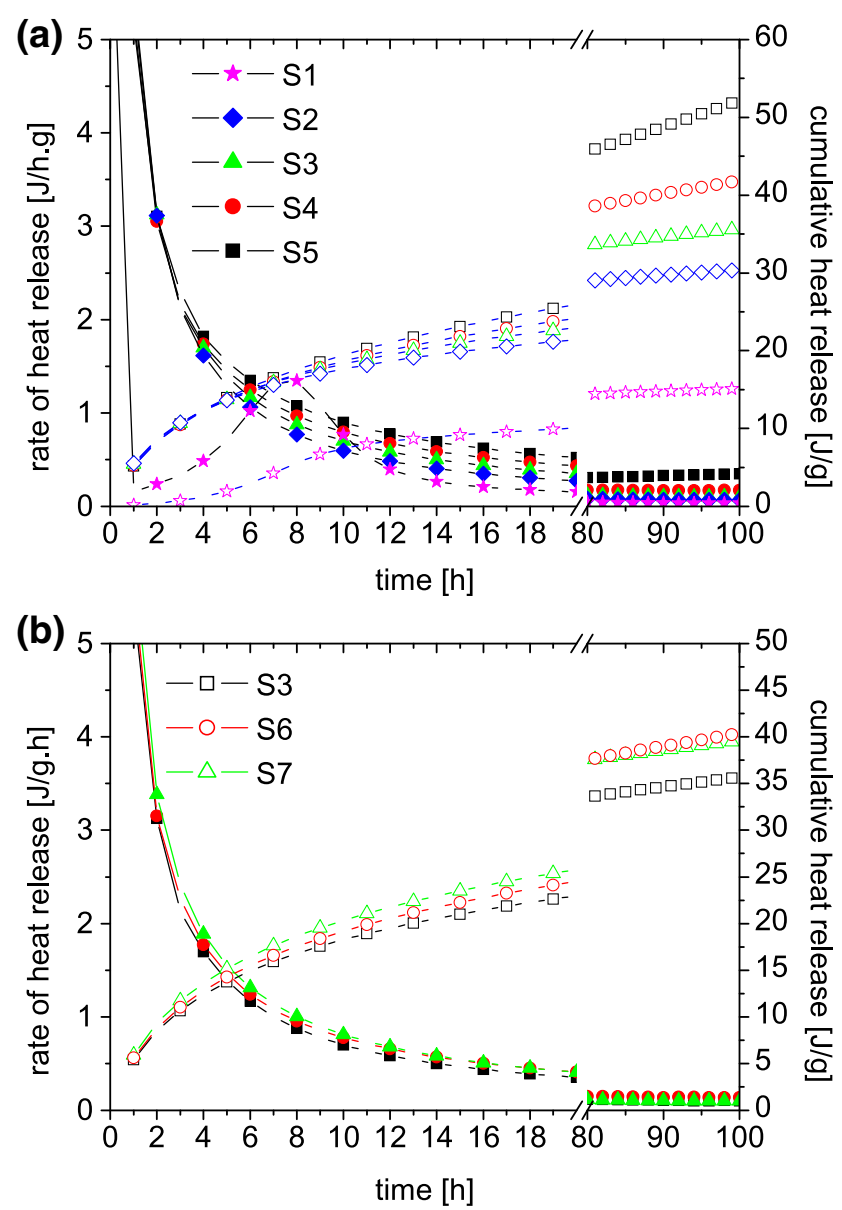

Fig. 1 Isothermal calorimetry curves of IP samples at $293 \mathrm{~K}$; a various $\mathrm{SiO}_{2} / \mathrm{Na}_{2} \mathrm{O}$ ratios of the activating solution, $\mathbf{b}$ various water contents in activating solution. Open symbols are used for cumulative heat, filled symbols for the rate of heat release

In all cases, the reactions were not completed after $100 \mathrm{~h}$, as the cumulative heat curves still have a positive slope. Thus, the system does continue to undergo microstructural transformations at latter times and this is also reflected in the strength development that has been rising for all time intervals tested (presented later, Table 5).

Regarding the effect of the water content in the activating solution, it was found that as the water level decreased, the recorded heat levels increased. The total amount of released heat after $100 \mathrm{~h}$ increased from $35 \mathrm{~J} / \mathrm{g}$ for $\mathrm{S} 3\left(\mathrm{H}_{2} \mathrm{O} / \mathrm{Na}_{2} \mathrm{O}\right.$ at 30.8) to about $40 \mathrm{~J} / \mathrm{g}$ for both $\mathrm{S} 6$ as 
well as S7 samples $\left(\mathrm{H}_{2} \mathrm{O} / \mathrm{Na}_{2} \mathrm{O}\right.$ at 26.8 and 22.2, respectively). However, these values do not take into account the dilution factor. If the data are recalculated to the actual amount of slag in the mixture, then the heat release is almost equal for all three samples after $20 \mathrm{~h}$, while after $100 \mathrm{~h}$, it is $8.5 \%$ higher for S6 compared to S3 and S7. This indicates that lowering the water content of the activating solution may contribute to a small extent to higher reactivity, but the contribution is rather small to draw conclusions.

\section{Thermogravimetry}

Thermal analysis was used in order to quantify the amount of residual water in formed IP samples. Typically, three types of remnant waters are distinguished: (a) "free" water, which is physically bound water present in a thin surface layer as well as situated in intergranular places; (b) "interstitial" water, which is chemically bound water typically associated with the activating cation and (c) "hydroxyl" water-that is, $\mathrm{OH}$ groups [26].

TGA curves presented in Fig. 2, showed a significant weight loss below $\sim 523 \mathrm{~K}$ in all investigated samples. This weight loss was due to "free" and "interstitial" water loss during heating. Still, considering that the samples had been subjected to freeze drying before measurement, a significant amount of "free" water had been already removed and, therefore, this weight loss should be attributed predominantly to "interstitial" water.

TGA curves further revealed that the weight loss gradually continued up until 773-973 K depending on the sample, due to the loss of "hydroxyl" water [27], where it stopped. The total weight loss increased from about $6 \mathrm{wt} \%$ for S1 sample to approximately $20 \mathrm{wt} \%$ for the S5 sample, although the highest water content was introduced in S1 sample (see Table 2). This phenomenon is probably connected to the increased amount of $\mathrm{Na}$ ions (in samples with lower $\mathrm{SiO}_{2} / \mathrm{Na}_{2} \mathrm{O}$ ratio), as it is known that $\mathrm{Na}$ keeps a relatively large amount of associated water in the IP structure [26, 27]. Unlike hydrated cements, it has been suggested [28] that this water is not bonded in the structure and is positioned together with the $\mathrm{Na}$ ions between the polymeric chains in the binder. This seems to be well in line with other results on low-calcium binders, where results from NMR spectroscopy [29] as well as gas sorption and positron annihilation lifetime spectroscopy on superficially dried samples [30] also suggested free and mobile water within open pores. This is an interesting outcome of the work, as the binder appears to behave as a low-calcium one, despite the fact that $\mathrm{CaO}$ exceeds $20 \mathrm{wt} \%$. The above suggest an alkali-alkaline earth binder $\mathrm{Na}_{2} \mathrm{O}-\mathrm{CaO}-\mathrm{FeOx}-$ $\mathrm{Al}_{2} \mathrm{O}_{3}-\mathrm{SiO}_{2}-\mathrm{H}_{2} \mathrm{O}$, which resembles suggestions of others [31].

Regarding the samples with variable water levels but constant $\mathrm{SiO}_{2} / \mathrm{Na}_{2} \mathrm{O}$ ratio, the total weight loss dropped from $18 \mathrm{wt} \%$ (when the $\mathrm{H}_{2} \mathrm{O} / \mathrm{Na}_{2} \mathrm{O}$ ratio was 30.8), down to $14 \mathrm{wt} \%\left(\mathrm{H}_{2} \mathrm{O} / \mathrm{Na}_{2} \mathrm{O}\right.$ ratio 26.8$)$, and eventually to approximately $12 \mathrm{wt} \%\left(\mathrm{H}_{2} \mathrm{O} / \mathrm{Na}_{2} \mathrm{O}\right.$ ratio 22.2). These results suggest that not only the amount of $\mathrm{Na}$ ions, but also the amount of initially introduced water has an influence on the amount of water which stays bonded in the IP structure. The dependence between weight loss after freeze drying and the $\mathrm{SiO}_{2} / \mathrm{Na}_{2} \mathrm{O}$ molar ratio is illustrated in Fig. 3.

\section{FTIR}

The IR spectra of the as-produced plasma converter slag, Fig. 4, showed three main peaks: at $467 \mathrm{~cm}^{-1}$
Fig. 2 TGA curves of IP samples reacted for 90 days: a various $\mathrm{SiO}_{2} / \mathrm{Na}_{2} \mathrm{O}$ ratios of the activating solutions, b various water contents in activating solution

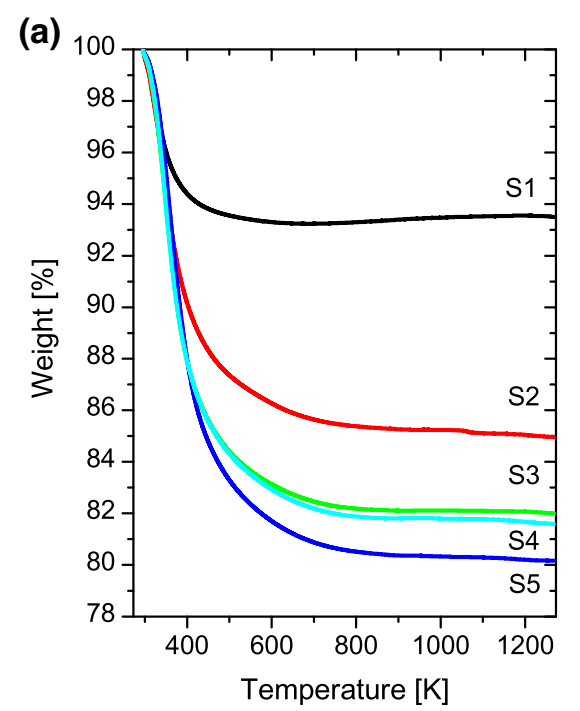

(b)

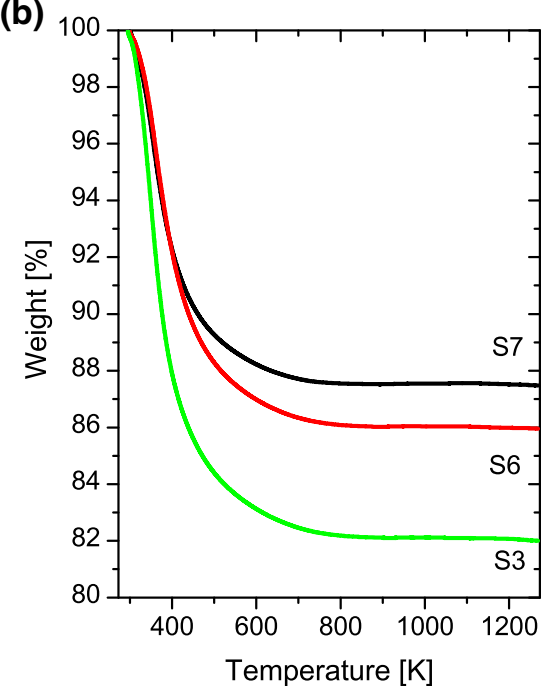




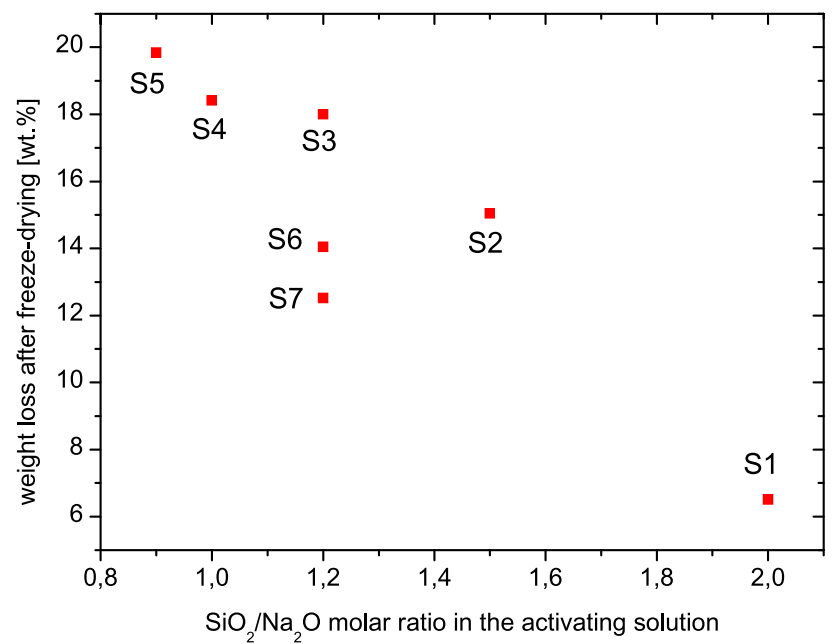

Fig. 3 Dependence of the weight loss after freeze-drying on the $\mathrm{SiO}_{2} / \mathrm{Na}_{2} \mathrm{O}$ molar ratio in the activating solution

corresponding to $\mathrm{T}-\mathrm{O}(\mathrm{T}=\mathrm{Al}, \mathrm{Si})$ bending vibration [32] at $695 \mathrm{~cm}^{-1}$ corresponding to $\mathrm{Si}-\mathrm{O}$ bending vibration of quartz [33], and at $902 \mathrm{~cm}^{-1}$ representing the asymmetric and symmetric $\mathrm{Si}-\mathrm{O}-\mathrm{T}$ stretching vibration $[34,35]$.

All these peaks were also present in the polymerised samples, but their position and shape were different. The peak of $467 \mathrm{~cm}^{-1}$ is shifted to lower wavenumber in all polymerised samples and was present at about $430 \mathrm{~cm}^{-1}$. On the other hand, the peak positioned at $902 \mathrm{~cm}^{-1}$ shifted towards higher wavenumbers, to about $949 \mathrm{~cm}^{-1}$. Both shifts represent the $\mathrm{TO}_{4}$ reorganisation [16] that took place during the polymerisation, considering that a peak position depends on the length and angle of the bond [36]. Both changes were attributed to the formation of a new reaction product suggesting the formation of IP.

Next to the peak shift, three new peaks were formed in all IP samples. A massive broad peak at about $3000-3600 \mathrm{~cm}^{-1}$ and a smaller peak at around $1650 \mathrm{~cm}^{-1}$ correspond to the vibration of $\mathrm{O}-\mathrm{H}$ groups in $\mathrm{H}_{2} \mathrm{O}$. The small peak at about $1400 \mathrm{~cm}^{-1}$ represents $\mathrm{C}-\mathrm{O}$ stretching vibrations [37], possibly of $\mathrm{Na}_{2} \mathrm{CO}_{3}$. The formation of $\mathrm{Na}_{2} \mathrm{CO}_{3}$ is quite common in IP and is attributed to the excess of $\mathrm{Na}^{+}$ions present which react with the atmospheric $\mathrm{CO}_{2}$. Isolated crystals morphologically appearing to be $\mathrm{Na}_{2} \mathrm{CO}_{3}$ were indeed observed by SEM in the S5 sample, which contains the highest amount of $\mathrm{Na}$.

\section{Microstructure}

Microstructural investigation revealed that a binder phase was formed in all samples after 90 days, Fig. 5. The formed binder phase was more dense for samples activated with the solution of $\mathrm{SiO}_{2} / \mathrm{Na}_{2} \mathrm{O}$ molar ratio equal to 1.2 or lower, which also coincides with the MIP results
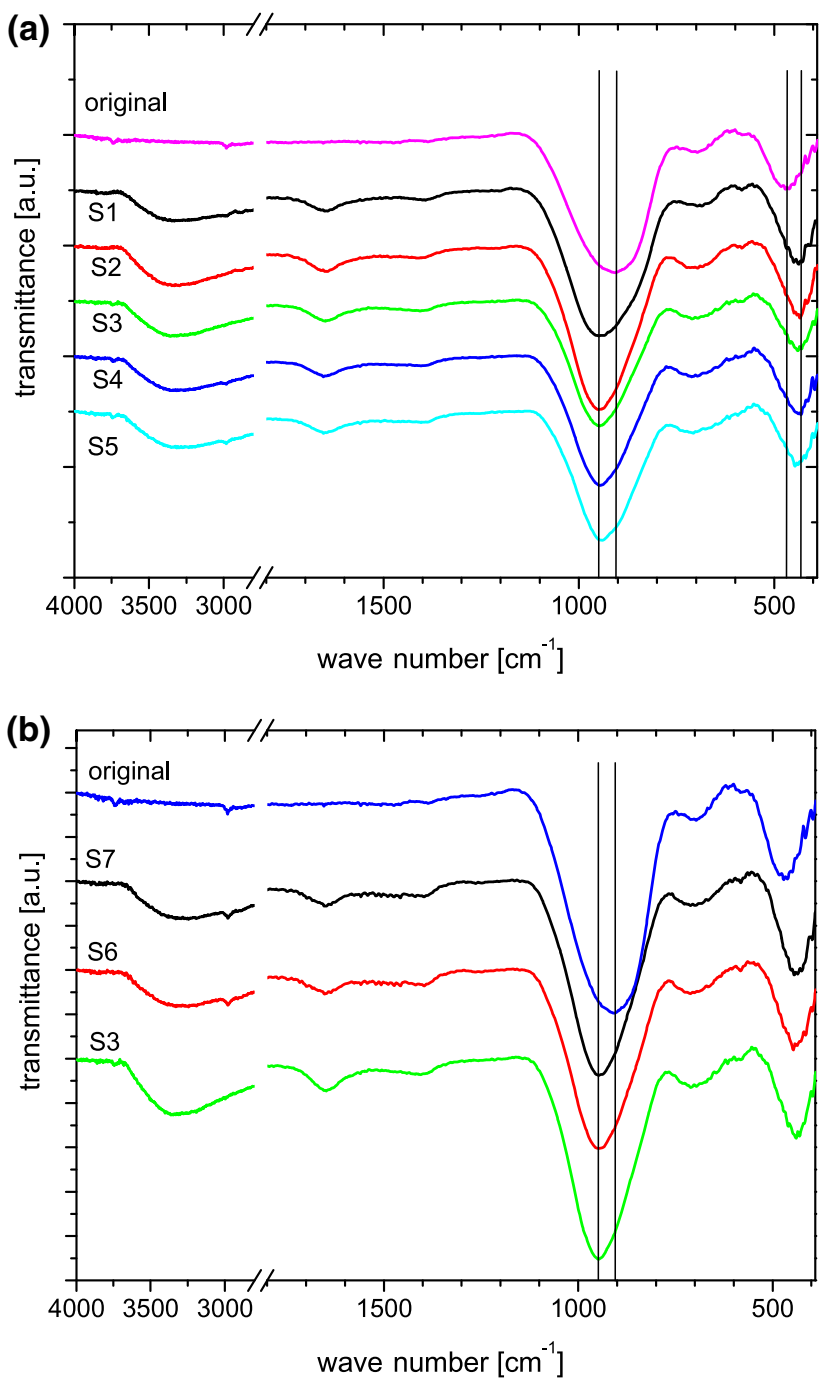

Fig. 4 FTIR curves of IP samples reacted for 90 days: a various $\mathrm{SiO}_{2} / \mathrm{Na}_{2} \mathrm{O}$ ratios of the activating solutions, $\mathbf{b}$ various water contents in activating solution

("Porosity" section). Another observation was that more slag particles were still visible in samples S1 and S2, indicating a lower extent of slag dissolution in these samples. This corresponds with the results from isothermal calorimetry ("Reactivity" section), where the heat release, influenced by the extent of dissolution, decreased with increased $\mathrm{SiO}_{2} / \mathrm{Na}_{2} \mathrm{O}$ molar ratio at early times. However, one can also see that the decreased $\mathrm{SiO}_{2} / \mathrm{Na}_{2} \mathrm{O}$ ratio resulted in more pronounced crack formation. Especially, in samples S4 and S5, numerous cracks were formed and they penetrate throughout the newly formed binder. Cracks were also formed in the S3 sample but in significantly smaller extent. In samples S1 and S2, no cracks were visible.

The crack formation is most probably caused by drying shrinkage and possibly also chemical and/or autogenous 

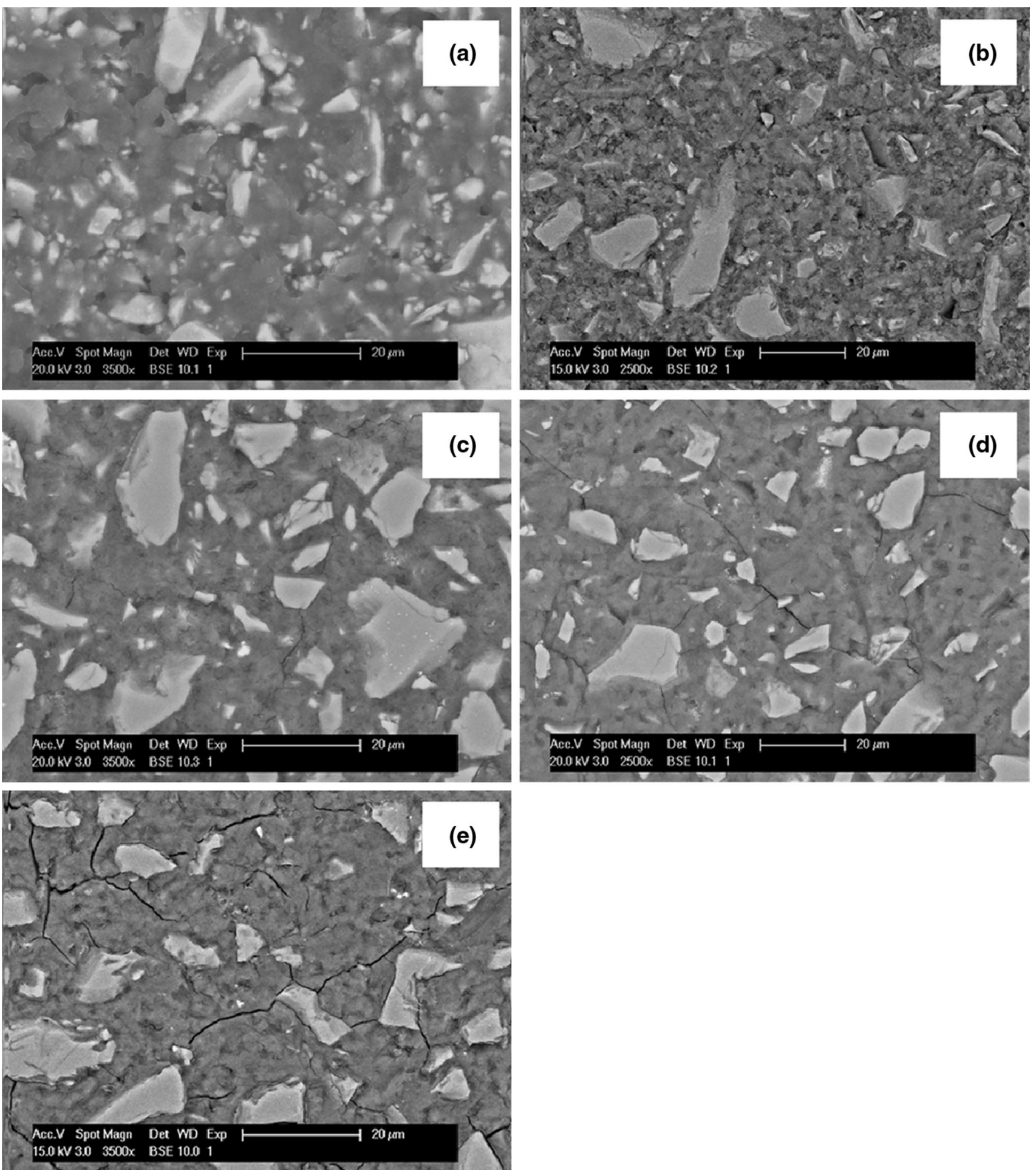

Fig. 5 Backscattered electron imaging micrographs of samples cured for 90 days a S1, b S2, c S3, d S4 and e S5

shrinkage during the curing of the samples. In that period, the majority of the water which had taken part in dissolution, hydrolysis, and polycondensation, eventually evaporates, causing drying shrinkage. In parallel, a small fraction of the water becomes chemically bonded in the IP binder, as data in "Thermogravimetry" section already demonstrated, whereas the IP itself undergoes structural changes and crosslinking. The above phenomena are valid per system; however, each formulation developed in the present work was unique in terms of $\mathrm{SiO}_{2} / \mathrm{Na}_{2} \mathrm{O}$ and $\mathrm{H}_{2} \mathrm{O} /\left(\mathrm{Al}_{2} \mathrm{O}_{3}+\mathrm{SiO}_{2}\right)$ 

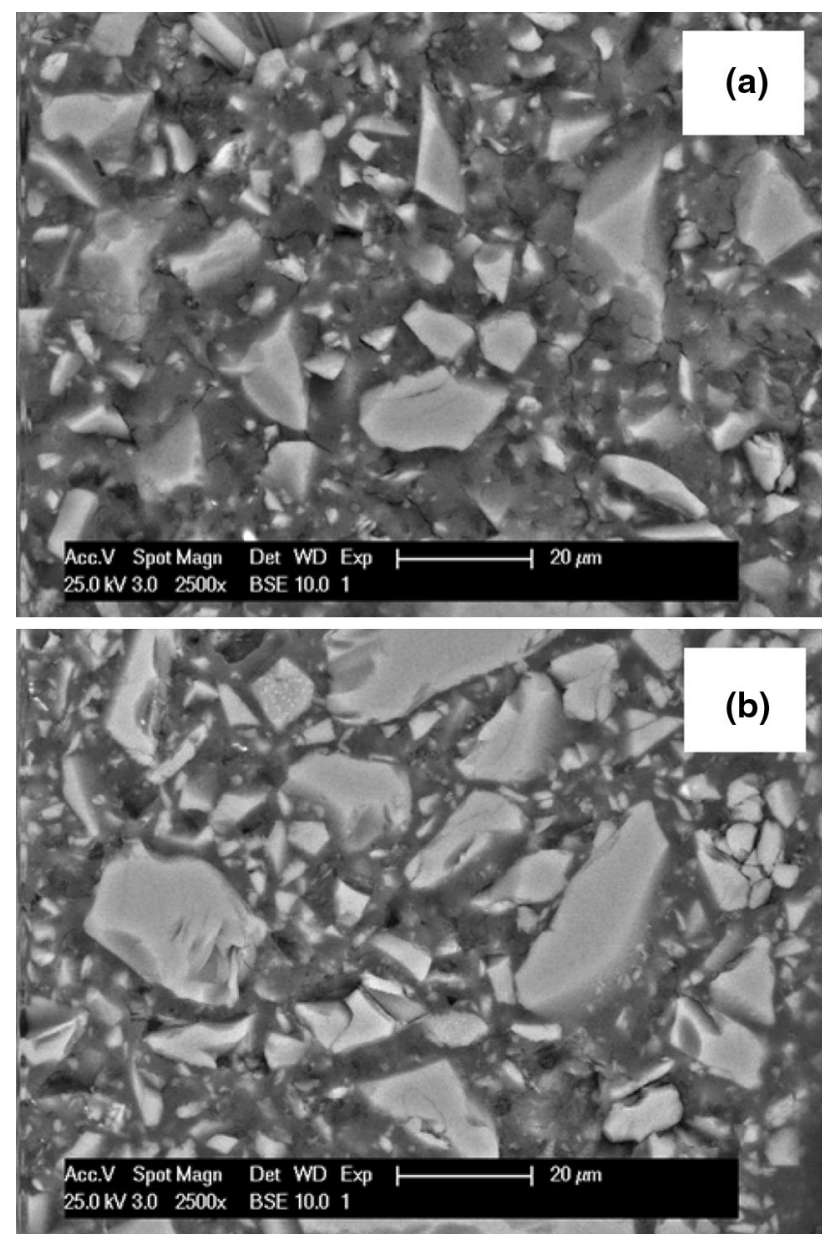

Fig. 6 Backscattered electron imaging micrographs of samples cured for 90 days a S6, b S7

ratios, which had an impact on the chemistry and structure of the binder, as well as, on the porous structure of the matrix (affecting capillary stress and water evaporation rates). To that extent, the shrinkage mechanisms taking place as well as the driving force towards crack formation can be only approached qualitatively herein.

The microstructure of both S6 and S7 samples, Fig. 6, is very similar and no major differences can be observed. The dissolution of original powder particles seems to be lower compared to the S3 sample, and the binder phase appeared more porous. This coincides with the MIP results ("Porosity" section), which revealed higher porosity in both samples. Still, a slightly higher amount of cracks was present, compared to S3 sample, although the cracks were very fine.

\section{Microchemistry of the Binder}

The WDS mapping of the main elements is presented in Fig. 7 whereas the results of the point micro-chemical analysis performed by EPMA are listed in Table 4. All main elements were present in both the unreacted powder as well as the binder phase formed. Except for $\mathrm{Na}$ and $\mathrm{Si}$, the concentration of all elements was higher in the original slag compared to the binder phase. The higher content of $\mathrm{Na}$ and $\mathrm{Si}$ in the binder is due to the activating solution. Still, data in Table 4 underestimate $\mathrm{Na}_{2} \mathrm{O}$ content as the theoretical calculations indicated an amount close to $6 \mathrm{wt} \%$. This deviation is primarily due to volatilisation of $\mathrm{Na}$ ions from the IP when subjected to high energy electron beams [38], in addition to the fact that a fraction of $\mathrm{Na}$ is not part of the binder (e.g. is present in the pore solution). $\mathrm{Al}$ and $\mathrm{Ca}$ appear homogenously distributed over the binder phase, whereas $\mathrm{Fe}$ is present both throughout the binder as well as in local areas. The latter may imply precipitation of a Fe-rich phase, possibly as a hydroxide or oxo-hydroxide. While $\mathrm{Ca}$ in the binding phase is claimed to provide charge compensation due to the presence of $\mathrm{Al}[32$, 39]; the position of $\mathrm{Fe}$ in the framework remains ambiguous. Several authors $[3,25]$ measured relatively high quantities of $\mathrm{Fe}$ in the binding phase of IP; however, no structural analysis was provided therein. Lemougna et al. [40] observed distorted tetrahedral or 5-coordinated site containing $\mathrm{Fe}^{3+}$, while Perera et al. [41] reported that $\mathrm{Fe}$ was present in IP in octahedral sites and only in samples heated up to $1173 \mathrm{~K}$, iron was present in tetrahedral coordination. This is a research question that requires further in-depth studies.

\section{Porosity}

The mercury intrusion curves obtained on mortar samples after 90 days are presented in Fig. 8. A discussion on the different techniques that can be employed to assess porosity is presented elsewhere [42] and it is acknowledged that all available techniques have inherent limitations; still, interesting trends can be revealed. According to the size, pores could be grouped into three categories: micropores that are $<2 \mathrm{~nm}$, mesopores which lay in the region 2-50 $\mathrm{nm}$ and larger pores which are $>50 \mathrm{~nm}$, including large capillary pores, macropores and cracks.

One can see that in all cases, the majority of the pores were smaller than $2 \mu \mathrm{m}$, and almost no pores were bigger than $10 \mu \mathrm{m}$. Moreover, the total porosity decreased significantly with increasing amount of alkalis. The $d_{50}$ of pore size decreased from $0.95 \mu \mathrm{m}$ in S1 sample to $0.07 \mu \mathrm{m}$ in the sample S4, while it increased rapidly to $0.45 \mu \mathrm{m}$ in sample S5. This was most probably due to the increased amount of cracks present in this sample. The amount of mesopores followed a reverse trend as it raised from less than $2 \%$ in S1 sample to $40 \%$ in sample S4 and then decreased to $32 \%$ in sample S5. The above is the outcome of an interplay between viscosity, known to increase as the $\mathrm{SiO}_{2} / \mathrm{Na}_{2} \mathrm{O}$ ratio increases, and reaction kinetics, known to 


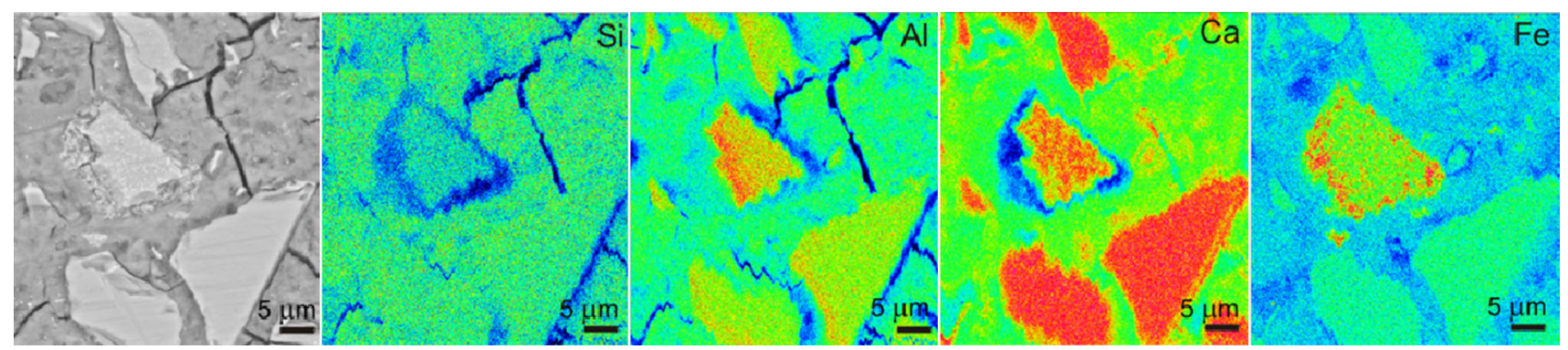

Fig. 7 Main elements distribution according to WDS mapping on a S3 sample reacted for 90 days. Increasing concentration from blue to green to red (Color figure online)

Table 4 Average chemical composition of binder $(B)$ and original particles $(P)$ obtained by EPMA analysis on the S3 and S6 samples, in wt\%

\begin{tabular}{|c|c|c|c|c|c|c|c|c|c|}
\hline & $\mathrm{Na}_{2} \mathrm{O}$ & $\mathrm{MgO}$ & $\mathrm{Al}_{2} \mathrm{O}_{3}$ & $\mathrm{SiO}_{2}$ & $\mathrm{CaO}$ & $\mathrm{FeO}$ & $\mathrm{TiO}_{2}$ & $\mathrm{~K}_{2} \mathrm{O}$ & $\mathrm{ZnO}$ \\
\hline$P$ & $4.7 \pm 0.1$ & $6.2 \pm 0.1$ & $8.6 \pm 0.3$ & $35.7 \pm 0.7$ & $23.8 \pm 0.2$ & $18.4 \pm 0.7$ & $1.5 \pm 0.3$ & $0.5 \pm 0.2$ & $1.4 \pm 0.1$ \\
\hline$B$ & $3.8 \pm 0.5$ & $4.9 \pm 0.3$ & $7.2 \pm 0.8$ & $45.1 \pm 3.9$ & $20.6 \pm 4.0$ & $16.5 \pm 0.7$ & $1.2 \pm 0.1$ & $0.4 \pm 0.1$ & $1.4 \pm 0.2$ \\
\hline
\end{tabular}

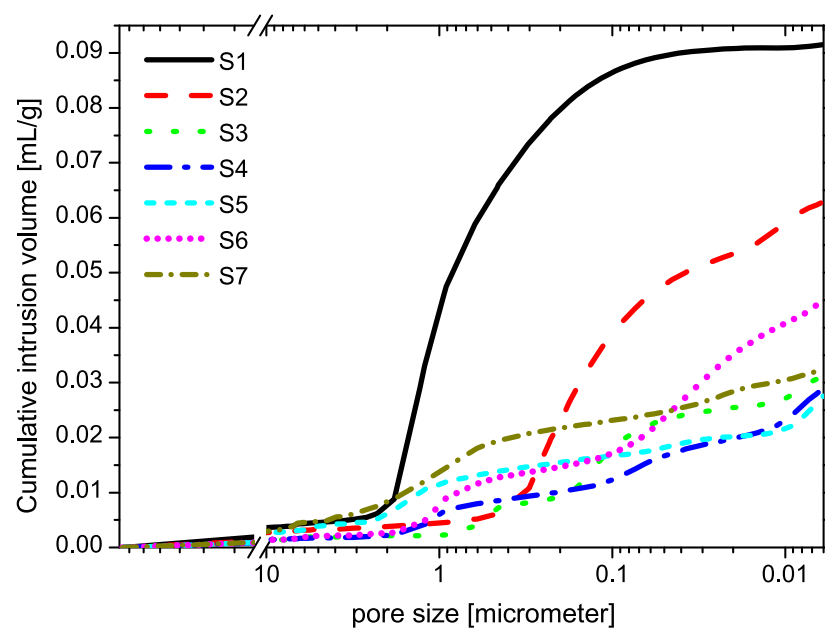

Fig. 8 Cumulative mercury intrusion volume versus pore size

be faster as the $\mathrm{SiO}_{2} / \mathrm{Na}_{2} \mathrm{O}$ ratio decreases, which is further perplexed by the varying $\mathrm{H}_{2} \mathrm{O} / \mathrm{Na}_{2} \mathrm{O}$ ratio. The bigger pores detected in samples S3, S4 and S5 are most probably indicating the presence of cracks, as no large pores were detected in the microstructure.

The increased amount of porosity at higher $\mathrm{SiO}_{2} / \mathrm{Na}_{2} \mathrm{O}$ ratio, which implies also higher $\mathrm{H}_{2} \mathrm{O} /\left(\mathrm{SiO}_{2}+\mathrm{Al}_{2} \mathrm{O}_{3}\right)$, is in agreement with the work by Linzcano et al. [26]., where they observed that the fraction of open porosity increases with increasing $\mathrm{H}_{2} \mathrm{O} /\left(\mathrm{SiO}_{2}+\mathrm{Al}_{2} \mathrm{O}_{3}\right)$ ratio. Furthermore, they claimed that the amount of "free" water has the dominant effect on inorganic polymer porosity, as it is the "free" water which stays entrapped in intergranular spaces and after aging leaves a large amount of pores in the IP structure. Although the "free" water was not determined in this study, the $\mathrm{H}_{2} \mathrm{O} / \mathrm{Na}_{2} \mathrm{O}$ molar ratios listed in Table 2 give a good indication on the highest and the lowest amount of "free" water, which were present in S1 and S5 samples, respectively. The role of $\mathrm{H}_{2} \mathrm{O}$ has been also presented in the work of Okada et al. [43], and the conclusions verify the trend also found in this work.

The decrease of water content in the activating solution did not result in further porosity reduction. Compared to S3, sample S6 had higher levels of mesopores (43\%), whereas in sample S7, the amount of mesopores was similar to S3 $(26 \%)$ while the quantity of coarser pores is higher. This transition to larger average pores' size can be explained by the lower fluidity of the samples, caused by the limited amount of water (s:1 equalled to 2.2 in S3, compared to 1.9 and 1.7 in the case of S6 and S3, respectively), which probably resulted in poor particle packing.

\section{Mechanical Properties}

The compressive strength results are listed in Table 5. A clear influence of the activating solution's $\mathrm{SiO}_{2} / \mathrm{Na}_{2} \mathrm{O}$ on the mechanical strength is visible after 7 days. Sample $\mathrm{S} 4$ appears to be an exception, but this phenomenon is not visible at later ages. The compressive strength of the S1 and S2 samples was very low after 7 days of reaction, but one should keep in mind that the S1 sample had not set at that time. Moreover, the compressive strength of this sample remained very low for the entire studied period, and even after 90 days, it was lower than $3 \mathrm{MPa}$, although the samples appeared to be hard. This indicates that although 
Table 5 Compressive strength of samples activated with solutions of differing molarities and water contents, in $\mathrm{MPa}$

\begin{tabular}{lrrr}
\hline Sample & \multicolumn{1}{l}{ 7D } & \multicolumn{1}{c}{ 28D } & \multicolumn{1}{c}{$90 \mathrm{D}$} \\
\hline S1 & $1.1 \pm 0.3$ & $2.4 \pm 0.4$ & $2.9 \pm 0.3$ \\
S2 & $3.3 \pm 0.7$ & $23.8 \pm 1.6$ & $45.0 \pm 3.8$ \\
S3 & $24.1 \pm 0.6$ & $71.7 \pm 1.7$ & $88.3 \pm 4.7$ \\
S4 & $16.4 \pm 1.3$ & $78.1 \pm 5.6$ & $88.9 \pm 5.6$ \\
S5 & $32.5 \pm 0.6$ & $81.3 \pm 6.3$ & $88.2 \pm 5.7$ \\
S6 & $16.3 \pm 0.1$ & $61.2 \pm 4.2$ & $83.4 \pm 2.8$ \\
S7 & $35.1 \pm 1.3$ & $81.0 \pm 5.4$ & $112.6 \pm 2.9$ \\
\hline
\end{tabular}

activation of the $\mathrm{S} 1$ sample resulted in glass dissolution and gel formation, this was very slow and thus the formed binder was too weak. Regarding the S2 sample, a significant increase in mechanical strength can be seen, both between 7 and 28 days, as well as between 28 and 90 days. Samples activated with the solution of the $\mathrm{SiO}_{2} / \mathrm{Na}_{2} \mathrm{O}$ molar ratio of 1.2 or lower, developed equally high mechanical strength of $88 \mathrm{MPa}$ after 90 days. At earlier stages, small differences between these samples were visible, but these diminished gradually with time. The fact that $\mathrm{SiO}_{2} / \mathrm{Na}_{2} \mathrm{O}$ molar ratios lower than $1.2 \mathrm{did}$ not result in further increase in mechanical strength is quite typical for IP, where an optimum occurs in most systems. This optimum between composition in the activating solution and mechanical strength can be attributed to a range of factors. Predominantly, it is due to different reaction kinetics and products for the different activating solutions used, but the increased amount of the $\mathrm{Na}^{+}$associated water, linked to an extensive network of cracks, as well as the excess of $\mathrm{Na}$ ions, resulting to a possible stress build-up due to carbonation, should be also acknowledged.

Decreased water contents in the activating solution in sample S6 resulted in slightly slower strength development compared to S3, which, however, was comparable (within standard deviation) with the obtained results after 90 days of curing. This is most probably due to higher porosity of this sample compared to S3. Further decrease of water content in sample S7 resulted in the highest compressive strength recorded, for all curing times, and after 90 days of reaction, the strength was $27 \%$ higher than that of the S3 sample. This could be attributed to the higher particle packing density, evident in Fig. 8, as well as the higher particles/binder ratio.

\section{Conclusions}

Inorganic polymers (IP) were synthesised using a vitrified $\mathrm{CaO}-\mathrm{Al}_{2} \mathrm{O}_{3}-\mathrm{FeO}-\mathrm{SiO}_{2}$ slag consisting of $98 \mathrm{wt} \%$ amorphous phase. The microstructure of all IP developed consisted of remnant slag particles and a $\mathrm{Na}_{2} \mathrm{O}-\mathrm{CaO}-$ $\mathrm{FeOx}-\mathrm{Al}_{2} \mathrm{O}_{3}-\mathrm{SiO}_{2}-\mathrm{H}_{2} \mathrm{O}$ binder. Water was predominantly "free" and "interstitial", whereas FTIR results revealed peak shifts, as expected for the new IP binder formed. The $\mathrm{d}_{50}$ pore size in the pastes varied from 0.95 to $0.07 \mu \mathrm{m}$, depending on the activating solution used. All IP mortars developed, showed mechanical strength which increased over time.

In more detail, samples activated with a solution of $\mathrm{SiO}_{2} / \mathrm{Na}_{2} \mathrm{O}$ molar ratio of lower than 1.2 , reached a compressive strength of $88 \mathrm{MPa}$ after 90 days of curing. Yet, these samples were also prone to crack formation. On the other hand, samples activated with a solution of $\mathrm{SiO}_{2} / \mathrm{Na}_{2} \mathrm{O}$ molar ratio of 2.0 did not set after 3 days, and after 90 days of curing reached mechanical strength of only $3 \mathrm{MPa}$. An activating solution with a $\mathrm{SiO}_{2} / \mathrm{Na}_{2} \mathrm{O}$ molar ratio ranging between 1.5 and 1.2, appeared to offer an optimum in terms of compressive strength and minimum crack formation.

In an effort to further improve the properties, the water content in the activating solution was decreased. Results were indeed better. A very dense microstructure with only sparse cracks was obtained, having a compressive strength of $112 \mathrm{MPa}$ after 90 days of curing.

The results herein demonstrate that the choice of the activating solution is a parameter with a profound impact on the final microstructure and properties. By following a sequential optimisation path, IP of high compressive strength can be obtained while still maintaining a straightforward casting process. This opens up a realistic opportunity for the upgrading of these slags and the production of added value materials.

Acknowledgments Authors are grateful for funding to Agentschap voor Innovatie door Wetenschap en Technologie (IWT) and Group Machiels, Grant 100517 "Closing the Circle \& Enhanced Landfill Mining as part of the Transition to Sustainable Materials Management". YP is thankful to the Research Foundation Flanders for the post-doctoral fellowship. We also gratefully acknowledge support from the Hercules Foundation (Project ZW09-09) for the use of the EPMA system.

\section{References}

1. Byun Y, Cho M, Hwang S.-M, Chung J (2012) Thermal plasma gasification of municipal solid waste (MSW). In: Yun Y (ed) Gasification for practical applications. InTech

2. Yan P, Pandelaers L, Machiels L, Pontikes Y, Geysen D, Guo M, Blanpain B (2015) Effect of gas-slag interaction on valorisation of refuse derived fuel treated with plasma gasification. Miner Process Extr Metall 124(2):76-82. doi:10.1179/1743285514Y.0000000074

3. Machiels L, Arnout L, Jones P, Blanpain B, Pontikes Y (2014) Inorganic polymer cement from Fe-silicate glasses: varying the activating solution to glass ratio. Waste Biomass Valoriz 5:411-428. doi:10.1007/s12649-014-9296-5

4. Pontikes Y, Machiels L, Onisei S, Pandelaers L, Geysen D, Jones PT, Blanpain B (2013) Slags with a high Al and Fe content as 
precursors for inorganic polymers. Appl Clay Sci 73:93-102. doi:10.1016/j.clay.2012.09.020

5. Shikabe H, Takamiya K, Hoshizawa Y, Kato Y, Tanaka H, Kotani K, Nishi T, Takada J (2005) Development of high-performance direct melting process for municipal solid waste. Nippon Steel Tech Rep 92:22-29

6. Themelis NJ (2007) Thermal treatment review: global growth of traditional and novel thermal treatment technologies. Waste Manag World July-August:37-45

7. Ducharme C (2010) Technical and economic analysis of plasmaassisted waste-to-energy processes. MSc thesis, Columbia University

8. Kalinkin AM, Kumar S, Gurevich BI, Alex TC, Kalinkina EV, Tyukavkina VV, Kalinnikov VT, Kumar R (2012) Geopolymerization behavior of $\mathrm{Cu}-\mathrm{Ni}$ slag mechanically activated in air and in $\mathrm{CO}_{2}$ atmosphere. Int $\mathrm{J}$ Miner Process 112-113:101-106. doi:10.1016/j.minpro.2012.05.001

9. Mellado A, Catalan C, Bouzon N, Borrachero MV, Monzo JM, Paya J (2014) Carbon footprint of geopolymeric mortar: study of the contribution of the alkaline activating solution and assessment of an alternative route. RSC Adv 4:23846-23852. doi:10.1039/ c4ra03375b

10. Turner LK, Collins FG (2013) Carbon dioxide equivalent $\left(\mathrm{CO}_{2}-\mathrm{e}\right)$ emissions: a comparison between geopolymer and OPC cement concrete. Constr Build Mater 43:125-130. doi:10.1016/j.con buildmat.2013.01.023

11. Alemán J, Chadwick AV, He J, Hess M, Horie K, Jones RG, Kratochvíl P, Meisel I, Mita I, Moad G, Penczek S, Stepto RFT (2007) Definitions of terms relating to the structure and processing of sols, gels, networks, and inorganic-organic hybrid materials (IUPAC Recommendations 2007). Pure Appl Chem 79:1801-1829

12. Davidovits J (1991) Geopolymers. J Therm Anal Calorim 37:1633-1656. doi:10.1007/bf01912193

13. Onisei S, Pontikes Y, Lemmens P, Machiels L, Jones PT, Coletti B, Blanpain B (2012) Synthesis of inorganic polymers from granulated slag of secondary copper production. In: Nzihou A, Castro $\mathrm{F}$ (eds) 4th international conference on engineering for waste and biomass valorisation, Porto, pp 700-705

14. Onisei S, Pontikes Y, Van Gerven T, Angelopoulos GN, Velea T, Predica V, Moldovan P (2012) Synthesis of inorganic polymers using fly ash and primary lead slag. J Hazard Mater 205-206:101-110. doi:10.1016/j.jhazmat.2011.12.039

15. Komnitsas K, Zaharaki D, Perdikatsis V (2007) Geopolymerisation of low calcium ferronickel slags. J Mater Sci 42:3073-3082. doi:10.1007/s10853-006-0529-2

16. Komnitsas K, Zaharaki D, Perdikatsis V (2009) Effect of synthesis parameters on the compressive strength of low-calcium ferronickel slag inorganic polymers. J Hazard Mater 161:760-768. doi:10.1016/j.jhazmat.2008.04.055

17. Maragkos I, Giannopoulou IP, Panias D (2009) Synthesis of ferronickel slag-based geopolymers. Miner Eng 22:196-203. doi:10.1016/j.mineng.2008.07.003

18. Sakkas K, Nomikos P, Sofianos A, Panias D (2013) Inorganic polymeric materials for passive fire protection of underground constructions. Fire Mater 37:140-150. doi:10.1002/fam.2119

19. Yamaguchi N, Nagaishi M, Kisu K, Nakamura Y, Ikeda K (2013) Preparation of monolithic geopolymer materials from urban waste incineration slags. J Ceram Soc Jpn 121:847-854

20. Jones PT, Geysen D, Tielemans Y, Van Passel S, Pontikes Y, Blanpain B, Quaghebeur M, Hoekstra N (2013) Enhanced Landfill Mining in view of multiple resource recovery: a critical review. J Clean Prod 55:45-55. doi:10.1016/j.jclepro.2012.05. 021

21. Rietveld HM (1966) A method for including the line profiles of neutron powder diffraction peaks in the determination of crystal structures. Acta Crystallogr 21:A228
22. Rietveld HM (1969) A profile refinement method for nuclear and magnetic structures. J Appl Crystallogr 2:65-71

23. Duxson P, Fernández-Jiménez A, Provis JL, Lukey GC, Palomo A, van Deventer JSJ (2007) Geopolymer technology: the current state of the art. J Mater Sci 42:2917-2933. doi:10.1007/s10853006-0637-z

24. Yao X, Zhang Z, Zhu H, Chen Y (2009) Geopolymerization process of alkali-metakaolinite characterized by isothermal calorimetry. Thermochim Acta 493:49-54. doi:10.1016/j.tca. 2009.04.002

25. Onisei S, Lesage K, Blanpain B, Pontikes Y (2015) Early age microstructural transformations of an inorganic polymer made of fayalite slag. J Am Ceram Soc. doi:10.1111/jace.13548:10.1111/ jace. 13548

26. Lizcano M, Gonzalez A, Basu S, Lozano K, Radovic M (2012) Effects of water content and chemical composition on the structural properties of alkaline activated metakaolin-based geopolymers. J Am Ceram Soc 95:2169-2177. doi:10.1111/j. 1551-2916.2012.05184.x

27. Kuenzel C, Vandeperre LJ, Donatello S, Boccaccini AR, Cheeseman C (2012) Ambient temperature drying shrinkage and cracking in metakaolin-based geopolymers. J Am Ceram Soc 95:3270-3277. doi:10.1111/j.1551-2916.2012.05380.x

28. Barbosa VFF, MacKenzie KJD, Thaumaturgo C (2000) Synthesis and characterisation of materials based on inorganic polymers of alumina and silica: sodium polysialate polymers. Int $\mathbf{J}$ Inorg Mater 2:309-317. doi:10.1016/S1466-6049(00)00041-6

29. Duxson P, Lukey GC, Separovic F, van Deventer J (2005) Effect of alkali cations on aluminum incorporation in geopolymeric gels. Ind Eng Chem Res 44:832-839. doi:10.1021/ie0494216

30. Vance ER, Hadley JH, Hsu FH, Drabarek E (2008) Positron annihilation lifetime spectra in a metakaolin-based geopolymer. J Am Ceram Soc 91:664-666. doi:10.1111/j.1551-2916.2007. 02173.x

31. Glukhovsky VD (1967) Soil silicate articles and structures. Budivelnyk Publisher, Kiev

32. Komnitsas K, Zaharaki D (2007) Geopolymerisation: a review and prospects for the minerals industry. Miner Eng 20:1261-1277. doi:10.1016/j.mineng.2007.07.011

33. Saikia B, Parthasarathy G, Sarmah NC (2008) Fourier transform infrared spectroscopic estimation of crystallinity in $\mathrm{SiO}_{2}$ based rocks. Bull Mater Sci 31:775-779. doi:10.1007/s12034-0080123-0

34. Criado M, Fernández-Jiménez A, Palomo A (2007) Alkali activation of fly ash: effect of the $\mathrm{SiO}_{2} / \mathrm{Na}_{2} \mathrm{O}$ ratio: part I: FTIR study. Microporous Mesoporous Mater 106:180-191. doi:10. 1016/j.micromeso.2007.02.055

35. Prud'homme E, Michaud P, Joussein E, Clacens JM, Rossignol S (2011) Role of alkaline cations and water content on geomaterial foams: monitoring during formation. J Non-Cryst Solids 357:1270-1278. doi:10.1016/j.jnoncrysol.2010.12.030

36. Rees CA, Provis JL, Lukey GC, van Deventer JSJ (2007) In situ ATR-FTIR study of the early stages of fly ash geopolymer gel formation. Langmuir 23:9076-9082. doi:10.1021/la701185g

37. García Lodeiro I, Macphee DE, Palomo A, Fernández-Jiménez A (2009) Effect of alkalis on fresh C-S-H gels. FTIR analysis. Cem Concr Res 39:147-153. doi:10.1016/j.cemconres.2009.01.003

38. Morgan GB, London D (1996) Optimizing the electron microprobe analysis of hydrous alkali aluminosilicate glasses. Am Mineral 81:1176-1185

39. Kumar S, Kumar R, Mehrotra SP (2010) Influence of granulated blast furnace slag on the reaction, structure and properties of fly ash based geopolymer. J Mater Sci 45:607-615. doi:10.1007/ s10853-009-3934-5

40. Lemougna PN, MacKenzie KJD, Jameson GNL, Rahier H, Chinje Melo UF (2013) The role of iron in the formation of 
inorganic polymers (geopolymers) from volcanic ash: a $57 \mathrm{Fe}$ Mössbauer spectroscopy study. J Mater Sci 48:5280-5286. doi:10.1007/s10853-013-7319-4

41. Perera DS, Cashion JD, Blackford MG, Zhang Z, Vance ER (2007) Fe speciation in geopolymers with Si/Al molar ratio of 2. J Eur Ceram Soc 27:2697-2703. doi:10.1016/j.jeurcer amsoc.2006.10.006
42. Provis JL, van Deventer JSJ (2014) Alkali activated materials. State-of-the-Art Report, RILEM, TC 224-AAM

43. Okada K, Ooyama A, Isobe T, Kameshima Y, Nakajima A, MacKenzie KJD (2009) Water retention properties of porous geopolymers for use in cooling applications. J Eur Ceram Soc 29:1917-1923. doi:10.1016/j.jeurceramsoc.2008.11.006 